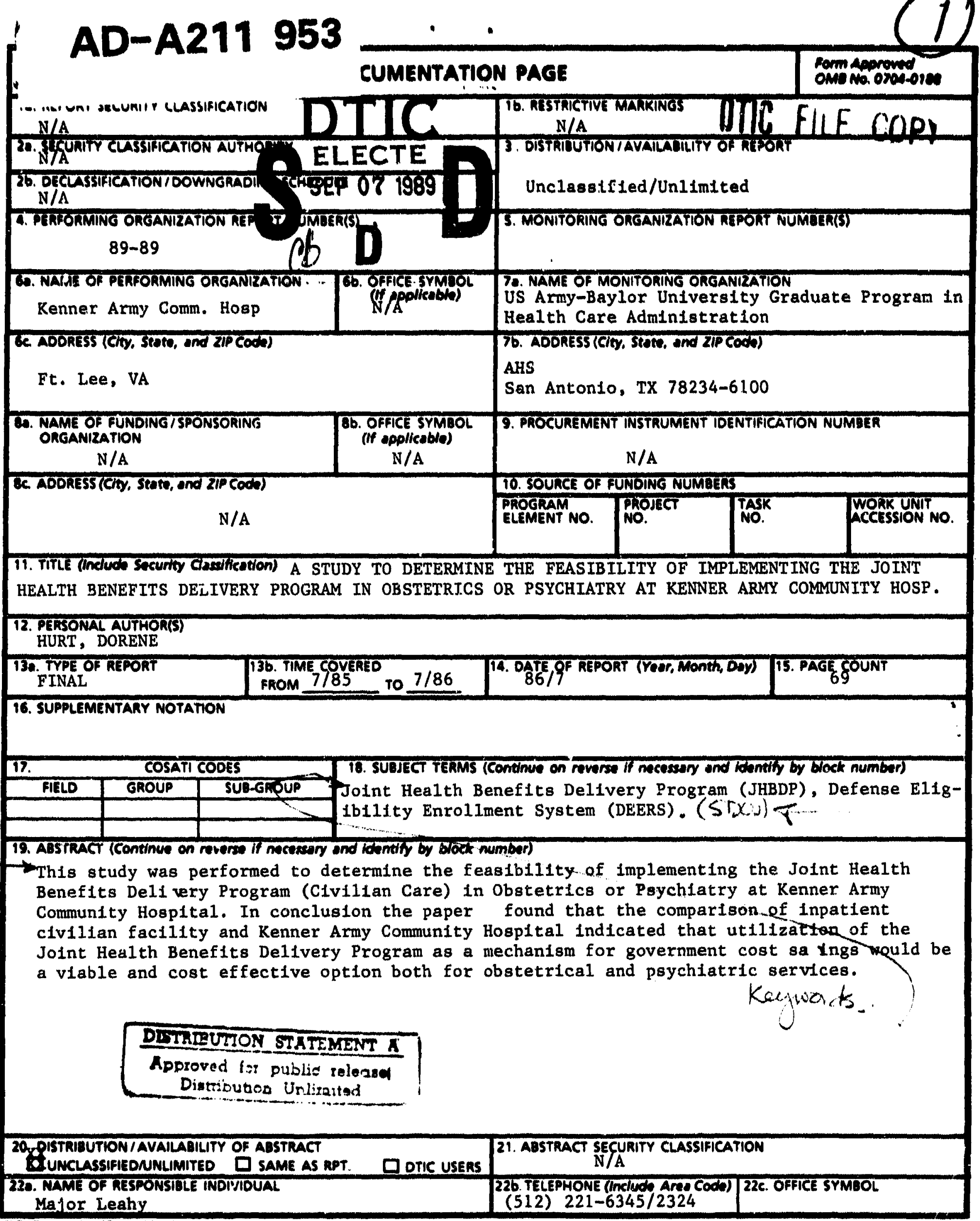




\title{
A STUDY TO DETERMINE
}

THE FEASIBILITY OF IMPLEMENTIN G THE JOINT HEALTH BENEFITS DELIVERY PROGRAM

IN OBSTETRICS OR PSYCHIATRY

AT KENNER ARMY COMMUNITY HOSPITAL

\begin{abstract}
A Graduate Research Project
Submitted to the Faculty of

Baylor University

in Partial Fulfinment of the

Requirements for the Degree
\end{abstract}

of

Master of Health Administration

by

Captain Dorene Hurt, MSC

July 1986

\begin{tabular}{|l|}
\hline Accesion ID \\
\hline NTIS CRA\&l \\
DTIC TAB \\
Unannounced \\
Justification
\end{tabular}

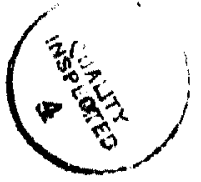


TABLE OF CONTENTS

LIST OF TABLES ......................... . . . . . . .

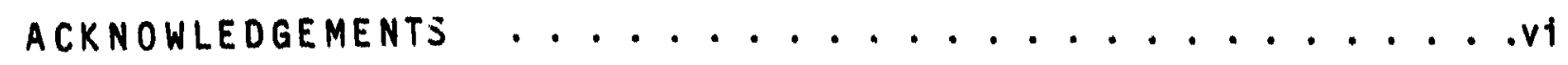
CHAPTER

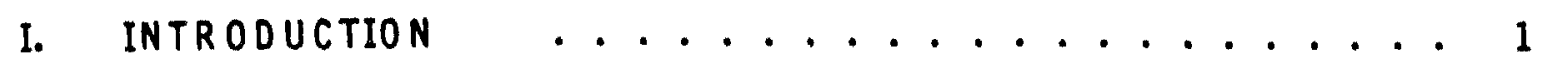

Joint Health Benefits Delivery Program .............. 2

Research Objectives, Criterla, Assumptions

and Limitations ................... 7

Research Methodology . . . . . . . . . . . . . . . . 9

II. JOINT HEALTH BENEFITS DELIVERY PROGRAM LITERATURE

AND PROGRAM REVIEW ..................... 13

General . . . . . . . . . . . . . . 13

Portsmouth Naval Medical Center . . . . . . . . . . . . 14

McDonald Army Com muntty Hospital . . . . . . . . . . 17

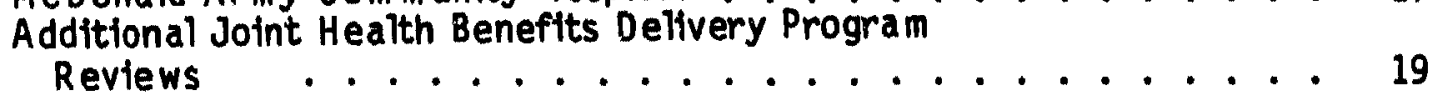

III. PSYCHIATRIC SERVICES ..................... 24

Inpatient Psychiatric Service Estim ate . . . . . . . . . . . . 24

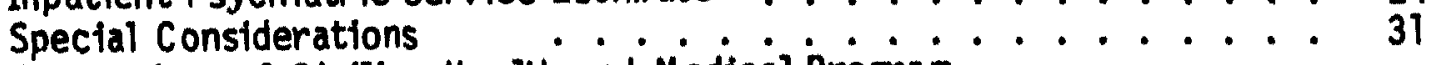

Comparison of Civilian Health and Medical Program

of the Uniformed Services and Joint Health Benefits

Defivery Program Psychiatric Service Costs 34

IV. OBSTETRICAL SERVICES ..................... 40

Inpatient Obstetrical Service Estim ate 40

Civitian Health and Medical Program of the Untform ed ${ }^{*} \cdot{ }^{*} \cdot{ }^{*} 40$

Services Maternity Care Provisions 4 a Prograin of . . . . . . . 44

Comparison of Civitian Health and Medical Program of
the Untformed Services and Joint Health Benefits

Delivery Program Obstetrical Service Costs . . . . . . . . 46

V. CIVILIAN HEALTH AND MEDICAL PROGRAM OF THE UNIFORMED SER VICES REFORM INITIATIVES ............... 49 
VI. CONCLUSION .................... 56

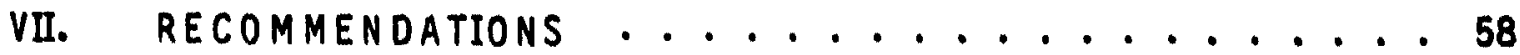

SELECTED BIBLIOGRAPHY ............. 61

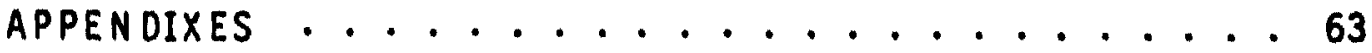

A. Medical Treatment Facility Health $C$ are Provider Contract (Ports mouth)

B. CHAMPUS/CHAMPVA Exploration of Benefits Statement with

C. Explanation of CHAMPUS/CHAMPVA Beneftts

D. Naval Hospital Portsmouth Catchment Area

E. Request for Procurem ent of Vascular Surgery Service Under the JHBDP Form

F. Medical Treatment $F$ acilities Health $C$ are Provider Contract (Fort Eustis)

G. Important Inform ation for Podiatry Clinic $P$ atients ( $H$ andout)

H. DOD Sponsors MACH Podiatry CHnic Article

I. Patient Data/Contract Doctors CHAMPUS Form

J. JHBDP Beneficiary Instructions for Fort Eustis Medical Department Activity

K. Podiatry Service Coverage Under CHAMPUS

L. CHAMPUS/CHAMPVA Explanation of Benefits Statement

M. CHAMPUS Health Care Sum mary by Primary Diagnosts (Fiscal Year 1984)

N. CHAMPUS Health Care Sum mary by Primary Diagnosis (Fiscal Yean 1985)

0. Request for Nonavallabllity Statement

P. Kenner Army Com muntty Hospital Mission Assignment List. 
Q. Health Insurance Plans Supplemental to

CHA MPIJS and/or Social Security Medicare l. isting

R. CHAMPUS/CHAMPVA Claim Form 
1. Psychiatry Codes According to Diagnosis

Psychiatry Group I

2. Psychiatry Codes According to Diagnosis Psychiatry Group II

3. Inpatient Psychiatric W ard Staffing Estim ate . . . . . 27

4. Estim ated Supply Expenses For Psychiatric $W$ ard (First Year)

5. Equipm ent Estim ate for Psychiatric W ard . . . . . . . 29

6. Renovation Cost Estim ate for Inpatient

Psychiatric Ward

7. Civilian Health and Medical Program of the Untformed

Services and Joint Health Benefits Delivery Program

Psychiatry Service Costs for Fiscal Years 1984 and $1985 \ldots . . .35$

8. Estim ated Supply Expenses for Obstetrics . . . . . . . . . 41

9. Equipm ent Estim ate for 0 bstetrics $W$ ard . . . . . . . 42 
ACKNOWLEDGEMENTS

Many thanks are extended to the Kenned Army Community Hospital Comptroller, Logistics and $P$ atient $A d m$ inistration Divisions for extensive assistance in the collection of research data on which the feasibility study was based. Special thanks to Colonel Jackie E. Bradford, Deputy Commander for Administration and Preceptor, for support and guidance throughout the research period.

vi 


\section{INTRODUCTION}

The Joint Health Benefits Delivery Program (JHBDP) is a voluntary program established by the Department of Defense in January 1983 to assists Commanders in obtaining additional health care providers in medical treatment facilities. The primary objectives are to maximize the resources of the factlity and reduce the cost of the Civilian Health and Medical Program of the Uniformed Services (CHAMPUS). Approxim ately 90,000 active duty personnel, Civilian Health and Medical Program of the Uniformed Services beneficiaries, and eligible civilians are located in the sixty-seven counties which make up Kenner Army Community Hospital's health service area. 1 According to the November 1985 MEDDAC Comptroller's Population Supported Report, of the approximately 90,000 potential beneficiaries 9865 were active duty, 19,585 retirees, 3785 active duty family members living on post, 4456 active duty fam ily members living off post, 41,325 family members of retirees and 10,312 civilians. ${ }^{2}$ Civilians are only counted as beneficiaries inasmuch as they are eligible for emergency care, occupational health services and to participate or benefit from some community health service programs.

Kenner Army Community Hospital experienced steady increases in the amount of funds expended to provide obstetrical and psychiatric services to its beneficiaries in fiscal years 1984 and 1985. The greatest percentage of fund expenditures, excluding personnel costs were for psychiatric and obstetrical services. Obstetrical and psychiatric services were being provided for active duty personnel via the Supplem ental Care Program and via Civilian Health and Medical Program of the Untformed Services for nonactive duty patlents. Medicare eligible patients received care at Kenner Army Com munity Hospital 
based on the availability of resources and in civilian facilities through self-pay, supplemental insurance arrangements, or the Medicare program.

Another factor which prompted the study was the opportunity to maximize the utilization of avallable space on the third floor of the facility (Appendix A). Having previously served as the obstetrical $w$ ard and newborn nursery prior to the term ination of obstetrical services in 1976, the area has been occupied by Red Cross Volunteers, the Nursing, Education, and Training Office, the housekeeping Contracting Officer's Representative, and utilized for storage.

In an effort to $\mathrm{maximize}$ resources and reduce patient care costs in obstetrical or psychiatric services the executive management at Kenner Army Community Hospital requested that research be conducted to determine the feasibility of implementing the Joint Health Benefits Delivery Program in obstetrics or psychiatry, with particular em phasis on cost efficiency, effectiveness, and patient participation.

\section{Joint Health Benefits Delivery Program}

\section{BACKGROUND}

The Joint Health Benefits Delivery Program (JHBDP) is a Department of Defense (COD) directed program established on 10 January 1983 IA W DOD 6010.12. The purpose of the program is to integrate specific $O$ Civilian Health and Medical Program of the Untformed Services and medical treatment facility (MTF) resources by aliowing Defense Eligibility Enrollm ent System (DEERS) enrolled Civilian Health and Medical Program of the Uniformed Services beneficiaries to receive inpatient related outpatient services, inpatient medical care, and ambulatory care surgery services from contracted civilian health care providers with military medical treatment facility privileges. 3 Implemented 
by the medical treatment facility Commander, the Joint Health Benefits Delivery Program objectives include reducing Civilian Health and Medical Program of the Uniformed Services costs, providing medical services that would otherwise be unavailable in the medical treatment facility, improving medical treatment facility productivity, increasing Civilian Health and Medical Program of the Uniformed Services beneficiary use of medical treatment facilities and assisting in the overall Department of Defense cost containm ent effort.

Under the program the health care provider establishes a contract with the hospital to provide inpatient services to Civilian Health and Medical Program of the Uniformed Services beneficiaries after negotiating and approval of a fee schedule and procedures listing with the Office of the Civilian Health and Medical Program of the Uniformed Services. An example of a provider - medical treatment facility contract is at Appendix A. The provider will not receive more than the Civilian Health and Medical Program of the Uniformed Services allowable charge. Outpatient services are part of the program only if directly related to inpatient care. The provider is paid by Civilian Health and Medical Program of the Uniformed Services under the standard Civilian Health and Medical Program of the Uniformed Services requirem ents and regulations. Under Civilian Health and Medical Program of the Uniformed Services, the patient must pay his or her cost share. 4 This is true even though the care is provided in a military hospital. Civilian Health and Medical Program of the Untformed Services beneficiaries with supplemental insurance or a major medical insurance plan such as Blue Cross/Blue Shield witl usually avoid any cost share charges. In any event, the provider bills the insurance plan first since Civilian Health and Medical Program of the Uniformed Services pays after all other plans have been utilized. Additionally, the yearly $\$ 50.00$ Civilian Health and Medical Program of the Uniformed Services deductible must be paid to the provider before 
Civilian Health and Medical Program of the Uniformed Services pays. Civilian Health and Medical Program of the Uniformed Services documents and assistance are available through coordination with the medical treatment facility's primary point of contact for Civilian Health and Medical Program of the Uniformed Services: the health benefits advisor.

Prospective Joint Health Benefits Delivery Program providers must be credentialed in accordance with Army Regulation 40-66 with a comprehensive privilege delineation recommendation from the Credentials Committee to the Commander prior to the implementation of a contract between the medical treatment facility and the provider. 5 Once approved by the Commander, the delineation of privileges will be signed by both parties and become an attachment to the contract or Memorandum of Understanding (MOU). Periodic review of the Joint Health Benefits Delivery Program's perform ance will be accomplished in the same $m$ anner that all providers are reviewed in accordance with applicable regulations and com $\mathrm{m}$ and policies.

Joint Health Benefits Delivery Program Benefits and Limitations.

If the service is available through the Joint Health Beriefits Delivery Program, the Civilian Health and Medical Program of the Untformed Services beneficiary does not have to seek care in the civilian community, pay a cost share to the hospital, or pay for ancillary services. Out-of-pocket physician costs to the patient should be reduced as the provider has the full use of ancillary services, clerical support, and medical support staff, such as licensed nurses. Examples of cost avoidance fees include physical therapy, laboratory tests, radiological tests and procedures, dressings, casts, and respiratory services. 
Limitations of the program are primarily based on the medical treatment facility's resources and the contractual arrangement that is established between the provider and the hospital. The major limitation, which is perceived by HSC and Commanders as a negative aspect of the program, is the ineligibility of active duty service members. Only personnel who are Civilian Health and Medical Program of the Uniformed Services eligible are permitted to participate in the Joint Hea!th Benefits Delivery Program.

Inpatient Cost share provisions of the Joint Health Benefits Delivery Program are as follows:

Active duty family member - no fee to provider; $\$ 7.30$ per day to the medical treatment facility for subsistence.

Retired family member - $25 \%$ of the allowable charge to provider; $\$ 7.30$ per day to the medical treatm ent facility for subsistence.

Retiree (enlisted) - $25 \%$ of the allowable charge to provider; no subsistence fee.

Retiree (officer) - $25 \%$ of the allowable charge to the provider; $\$ 7.30$ per day to the medical treatment facility for subsistence.

There is no yearly deductible requirement for inpatient care in a military facility, which almost always includes surgery, and there is no $\$ 25.00$ minimum fee, as is required under the standard Civilian Health and Medical Program of the Uniformed Serjices program. The $\$ 25.00$ minimum fee and yearly deductible waiver for inpatient services are considered special program benefits.

Under the Civilian Health and Medical Program of the Uniformed Services Program, a beneficiary is responsible for the first $\$ 50.00$ of Civilian Health and Medical Program of the Untformed Services-determined reasonable costs/charges for covered outpatient services and supplies during any fiscal year. The total outpatient deductible amount for 
two or more beneficiary members of the same famfly who subm it claims during the same fiscal year is $\$ 100.00$. Civilian Health and Medical Program of the Untformed Services pays 80 percent of the Civitian Health and Medical Program of the Untformed Servicesdetermined reasonable charges received by spouses and children of active duty members after the deductible has been met. The beneficiaries are responsible for the re $m$ aining 20 percent. Civilian Health and Medical Program of the Uniformed Services pays 75 percent of the Civilian Health and Medical Program of the Uniformed Services-determined reasonable charges received by retirees, spouses and children of retirees, spouses and children of deceased active duty members, and spouses and children of deceased retirees. The beneficiary is responsibie for the rem aining 25 percent.

Although numerous Joint Health Benefits Delivery Program changes are expected as the program develops in the outpatient services area, current policy includes a major limitation. Patients who receive outpatient care in the medical treatment facility by a Joint Heaith Benefits Delivery Program physician cannot receive inpatient care by the same physician since that provider is not permitted to refer patients to him or herself. The impact of the current policy is twofold. First, continuity of care can be compromised when the provider most aware of the patients' needs is not permitted to participate in inpatient care, even though qualified and avatlable. Secondly, active duty military and Department of the Army civilian physicians have to screeil patients for Joint Health Benefits Delivery Program providers to ensure that only those requiring inpatient services are seen by the Joint Health Benefits Delivery Program physician on an outpatient basis.

Recommended changes to the current policy include the contracting of a Joint Health Benefits Delivery Program provider under two simultaneous contracts. Under the Direct Health $\mathrm{C}$ are Provider Program a physician is retained under a personal services 
contract to provide services to all beneficiaries. Such a change would eliminate the restriction of Joint Health Benefits Delivery Program providers being permitted to provide outpatient services in an medical treatment facility. Screening by military and civilian physicians for the Joint Health Benefits Delivery Program physician would also no longer be necessary.

\section{Research Objectives, Criteria, Assumptions, and Limitations}

\section{Objectives}

1. Review the documentation that was used to establish at least two Joint Health Benefits Delivery Program programs within Department of Defense (Ft Eustis and Portsmouth Naval Medical Center).

2. Collect beneficiary demographic data to determine the size and characteristics of the population of concern.

3. Determine what psychiatric and obstetrical procedures or medical care the beneficiaries are receiving via Civilian Health and Medical Program of the Uniformed Services.

4. Ascertain the Civilian Health and Medical Program of the Uniformed Services roimbursement rate for proposed-inpatient services when received in a civilian inedical treatment facility. Determine the cost of the same services at Kenner Army Community Hospital.

5. Analyze cost data by comparing the cost of providing services under the Civilian Health and Medical Program of the Untformed Services Program and the Joint Health Benefits Delivery Program.

6. Determine the appropriate staffing level for psychiatric and obstetrical services under the Joint Health Benefits Delivery Program. 
7. Determ ine the additional facility and equipment requirements if psychiatric or obstetrical services are provided under the Joint Health Benefits Delivery Program.

3. Ascertain the impact of proposed Civilian Health and Medical Progran of the Unfformed Services reforms on the Joint Health Benefits Dellvery Program.

9. Present findings to the Com m and with recom mendations.

\section{Criterta}

1. The cost of providing the service under the Joint Health Benefits Delivery Program must be less than the cost of inpatient. or ambulatory surgery care in a civilian health care factlity utilizing the standard Civilian Health and Medical Program of the Uniformed Services Program.

2. Services to be considered under the program cannot require the construction of a separate facility.

\section{Assumptions}

1. Demographics of the Kenner Army Com munity Hospital catchment area will not significantly change.

2. No mission changes affecting Civilian Health and Medical Program of the Untformed Services beneficiaries will occur during the research period.

3. The medical treatment facility must not currently provide the psychiatric and obstetrical $m$ ission authorized services under consideration. Mission authorized services are those services that can be provided by the medical treatment facility and are listed in Appendix P. 
Limitations

1. Mission authorized and modified psychiatric and obstetrical services indicated on the Medical Department Activity's template (Appendix P) will be considered for inclusion in the proposed program.

2. Civilian Health and Medical Program of the Uniformed Services data such as Nonavailability Statement Sum m aries from October 1983 - September 1985 will be uttizized in the study.

3. Kenner Army Community Hospital workload data from October 1983 Septem ber 1985 will be uttilized in the study.

4. The program is 11 mited by the conditions stated in DOD 6010.12 , dated 10 January 1983, and Heaith Services Command letter HSOP-FF HQS HSC, 26 June 1984, subject: Implementation of Joint Health Benefits Delivery Program.

5. The program only applies to those personnel eligible for Civilian Health and Medical Program of the Untformed Services. It does not apply to active duty personnel or those persons eligible for Medicare based on age or disabtlity.

\section{RESEARCH METHODOLOGY}

A review of the literature was accomplished by reviewing documentation from existing programs as provided by the Health Services Command Patient Administration Division office and worklpad and Civilian Health and Medical Program of the Untformed Services utilization data from October 1983 -September 1985. The Civilian Health and Medical Program of the Uniformed Services beneficiary population in the catchment area was determined by examining Health Systems Agency data, Civilian Health and Medical 
Program of the Untformed Services Nonavallability Statement data and Civilian Health and Medical Program of the Uniformed Services Healthcare Sum $m$ aries.

The projected cost of ancillary personnel to support the practitioner, equipment and facility costs were calculated and based upon estimates provided by the Logistics Division, Civilian Personnel Office, Personnel Division and Comptroller's Division, Patient Administration Division health care statistical data at Kenner Army Com munity Hospital. For the services to be recommended under the Joint Health Benefits Delivery Program, the total cost of personnel, equipment, and factitity alterations should not exceed the cost of providing the service via Civilian Health and Medical Program of the Uniformed Services in a civilian facility.

Demographic and medical care data as described in the objectives was evaluated to determine the major commonalities in the population of concern and assisted in determining the types of psychiatric and obstetrical services that should be included in the Joint Health Benefits Delivery Program if it is to be implemented.

The financial feasibility of the Joint Health Benefits Delivery Program program was evaluated by comparing the Joint Health Benefits Delivery Program estimate for services at Kenner Army Community Hospital against the full Civilian Health and Medical Program of the Untformed Services allowable costs for the same or similar service provided in a civilian health care facility. Civilian Health and Medical Program of the Unfformed Services information was indicated in the Nonavallability Statements for Health Services Com mand and the Health Services Com mand Untform Chart of Accounts analysis of selected indicators. 6 The Joint Health Benefits Delivery Program costs must be less than the current Civilian Health and Medical Program of the Uniformed Services program costs. 
Example: civtlian hospital -

Amount Billed

inpatient podiatric professional services:

$\$ 450.00$

outpatient podiatric professional services:

$\underline{20.00}$

Total

$\$ 470.00$

Joint Health Beneftts Delivery Program in KACH -

Amount Billed

inpatient professional services:

$\$ 105.00$

inpatient hospital services:

7.30 per diem

outpatient clinic visit:

20.00

Total

$\$ 150.00$ *

*The program's savings potential is primarily in inpatient service costs. Outpatient fees are charged patients at the normal Ctvilian Health and Medical Program of the Untformed Services reimbursement rate for outpatient services. The above example is of an actual Civilian Health and Medical Program of the Untformed Services patient bill (Appendix B and $\mathrm{C}$ ).

1 Medical Department Activity, "Comptroller's Population Supported Report, Fort Lee, Virginia, Novem ber 1985.

2Ibid.

3U.S., Department of Defense Instruction, Joint Health Beneftts Delivery Program, No. 6010.12, February, 1983, pp. 1-6.

4U.S., Department of Defense, CHAMPUS Handbook, No, 6010.46-H, Aurora, Colorado, 1985, pp 10-16.

5U.S., Department of the Army Headquarters, United States Health Services Com $m$ and, Implementation of Joint Health Beneffts Delivery Program, June, 1984, pp. 1-8. 
6U.S., Department of the Army, Office of The Surgeon General, Medical Summary Report - Section IV, Nonavailability Statements, (MED 302, R-3), October 1984 September 1985, pp. 1-10. 
II. JOINT HEALTH BENEFITS DELIVERY PROGRAM LITERATURE AND PROGRAM REVIEW

\author{
General
}

Joint Health Benefits Delivery Program literature and program reviews were performed based upon avallable information since the program's February 1983 authorization. Given the newness of the program, a histomical literature base primarlly consisted of Department of Defense, Office of the Civitian Health and Medical Program of the Untformed Services (OCHAMPUS) and Health Services Command program justffication and implementation guidelines. The overall program objective was to provide medical treatment factlity Commanders a mechanism for providing services which would otherwise be unavatlable to Civilian Health and Medical Program of the Untformed Services beneficiarles in a military factlity. Simultaneously, significant savings in Civilian Health and Medical Program of the Untformed Services fund expenditures were anticipated. The Office of the Civilian Health and Medical Program of the Untformed Services has been tasked to provide statistical, pecuntary, program performance and uttization data to the Office of the Assistant Secretary of Defense for Health Affairs on an ongoing basts. Information found in recently published Civilian Health and Medical Program of the Untformed Services program literature and discussions during Health Beneftts Advisor Conferences indicate that sweeping changes within Civilian Health and Medical Program of the Untformed Services are $1 \mathrm{~m} m$ inent due to consistently increasing Civitian Health and Medical Program of the Unfformed Services costs.1 Regulated by Civilian Health and Medical Program of the Untformed Services policy, the Joint Health 
Benefits Delivery Program could be affected by any change. Navy, Air Force and Army inedical treatment facility Commanders have introduced the progran sparingly. A review i the literature revealed that podiatric, otorhinolargyngology, and urologic services comprised the bulk of Joint Healti. Benefits Delivery Program that were proposed or functioning. 2

Headquarters, Health Services Command retained the approval authority for all Arm y-proposed Joint Health Benefits Delivery Program arrangements. Upon expiration of agreem ents, renew al requests must also be forwarded for consideration to Headquarters, Health Services Com mand.

Reviews of Joint Health Benefits Delivery Program related documents were physically accomplished at Portsmouth Naval Medical Center and McDonald Army Community Hospital, Fort Eustis, Virginia. An overview of each facility's current program was provided by the respective Health Benefits Advisor. Inform ation specifying the development, execution and overall administration of each program was obtained. Additionally, other Joint Health Benefits Delivery Program reviews were conducted through examination of documentation for Joint Health Benefits Delivery Program's at the Forts Devens, Leavenworth, Benjam in Harrison and $\sin$ community hospitals and Fitzsimons Arm y Medical Center.

Portsmouth Naval Medical Center

As of the beginning of the 1986 fiscal year Portsmouth $N$ aval Medical Center was a training hospital with over 500 beds and a beneficiary population of approximately 292,373 in its catchment area. The distribution of the beneficiaries by category is indicated in Appendix $D$. Overall trends in the population indicated a steady growth in dependents of active duty and dependents of retired categories during the last four years. 
Vascular surgery needs that were previously performed under Civilfan Health and Medical Program of the Untformed Services were steadily increasing and absorbing significant amounts of both Civilian Health and Medical Program of the Unfformed Services and supplemental care monles. A vascular surgery Joint Health Benefits Delivery Program was recommended by several key medical staff members as a way to reduce supplemental care and Civilian Health and Medical Program of the Uniformed Services monies expended, assist beneficiaries by reducing their cost share, and take advantage of the opportunity for interns and residents to observe vascular surgery techniques. The hospital com $\mathrm{m}$ ander approved the request and subsequently assigned coordinating responsibilities to the fiscal officer.

Portsmouth Naval Hospital implemented a Joint Health Benefits Delivery Program for vascular surgery in November 1985. The hospital's fiscal officer was the primary coordinator for the program. Although the Health Benefits Advisor and Patient Administration vepartment are jointly responsible for the administrative and organizational requirements of a Joint Health Benefits Delivery Program, netther area informed of the program until February 1986. It $w$ as at this time that patient and sponsor inquiries concerning the reason for patient billing and queries about proper adm inistrative and billing procedures from the vascular surgeons were received. Form al notffication to the Health Benefits Advisor was not accomplished until March 1986, at which time a copy of the Provider Agreements were received, including a Civilian Health and Medical Program of the Uniformed Services-approved negotiated fee schedule signed by the three participating health care providers and the Com manding Officer of the Portsmouth $\mathrm{Naval}$ Medical Center on 15 November 1985 (Appendix C). Delays in the involvement of the Patient Administration Department in general, and the Health Benefits Advisor in particular, consistently resulted in numerous complaints from patients who had received vascular surgery services but had not been or only partially briefed on the Joint Health 
Benefits Delivery Program. Numerous complaints relative to payment delays were also received from the three participating vascular surgeons. Several vascular surgery patient billings were subsequently cancelled and the costs absorbed due to the $N$ aval Medical Center's absence of a comprehensive, well planned and advertised policy on the Joint Health Benefits Delivery Program. Inspector General inquiries and participating physician complaints about many vascular surgery procedures performed from November 1985 to March 1986 were still pending action in June 1986.

Coordination between the fiscal officer and Patient Adin inistration Department began in March 1986. The objective of the concerted effort was to properly plan the implementation of the Joint Health Benefits Delivery Program as prescribed by the DOD directive. Although no additional resources in terms of personnel, space, or equipment were to be made avatlable to the Patient Administration Department, a planned, coordinated program was expected to positively facilitate the accomplishment of all docum entation and reimbursement requirements. Initial actions included: careful review of the negotiated agreement with the three vascular surgeons, briefing the program's regulatory requirements to key hopsital personnel and participating providers, marketing the program throughout the Medical Center and local media, and establishment of administrative procedures to be followed when vascular surgery patients were treated under the Joint Health Benefits Delivery Program. Development of a form which briefly explained the program and treatment arrangements was quickly accomplished, then distributed for use (Appendix E). Responsibility for briefing potential patients $w$ as initially assigned to the affected departments. Patients were then supposed to be directed to the Health Benefits Advisor after signing the form for further explanation and completion of required Civilian Health and Medical Program of the Untformed Services' documents. Regular fallures in referring patients to the Health Benefits Advisor indicated a need for the Health Benefits Advisor to establish a procedure for periodic 
checking of department records. Periodic checks to balance the records and discover inconsistencies became effective program administration tools and resulted in significantly fewer complaints or regulatory om issions.

Costly lessons were learned by the providers and adin inistrators of the Joint Heaith Benefits Delivery Program at Portsmouth $\mathrm{Naval}$ Medical Center. Coordinated staff planning, command awareness and patient awareness were admittedly lacking prior to program implementation. Additional services are being identified and expected to be provided under the Joint Health Benefits Delivery Program at Portsmouth Naval Medical Center after patient and documentation proficiency is demonstrated using currrently established policies and procedures.

\section{MCDonald Army Com munity Hospital}

Podiatric services became available at McDonald Army Community Hospital, Fort Eustis, Virginia, under the Joint Health Benefits Delivery Program in October 1985. Contract agreement provisions approved by the Office of the Civilian Health and Medical Program of the Uniformed Services and signed by the provider and the hospital com mander are at Appendix E. Major conditions of the contract include: a Virginia State licensure requirement, personal liability coverage, clinical privilege application and approval, adherence to Civilian Health and Medical Program of the Untformed Services allowable payment policies and the Health Care Provider Agreement.

Prior to the effective date of the programs, McDonald Army Community Hospital notffied beneficiaries of the new program through the media, handouts, and presentations to the Fort Eustis active duty and retired communities (Appendix $G$ and $H$ ). No additional resources were provided to the Health Benefits Advisor who was tasked as primary coordinator of documentation completion. Non-active duty patients requiring podiatric 
services were routinely given an information paper which explained the Joint Health Benefits Delivery Prograin. Potential patients were given the option to participate in the voluntary program or receive a Statement of Nonavailability. A Statement of Nonavailability enabled the beneficiary to seek care under the standard Civillan Heaith and Medical Program of the Uniformed Services guidelines. If the patient elected to receive care at McDonald Army Community Hospital, patient data and contract documents which further clarified the program were completed in the department (Appendix I and J). Subsequent referral to the Health Benefits Advisor permitted expeditious processing of Civilian Health and Medical Program of the Uniformed Services forms.

Podiatric services were limited by the provisions of the contract and approved services covered under the Civilian Health and Medical Program of the Uniformed Services. Routine foot care by a podiatrist could be a Civilian Health and Medical Program of the Uniformed Services benefit if the patient had a diagnosis of a system ic disease that had resulted in a severe circulatory deficiency or desensitization of areas in the legs or feet. Covered services would include cutting or removal of corns, calluses or nails (Appendix K). Thorough documentation on the claim form was necessary to determine the medical necessity of the service(s). Identification of any systemic disease, symptoms or physical findings to establish the severity of the disease was critical. Generally, the existence of the following conditions permitted payment for routine foot care under the Civilian Health and Medical Program of the Uniformed Services: diabetts mellitus, chronic thrombophlebitis and peripheral neuropathies involving the feet. One hundred ninety-one approved procedures with associated fees were listed in the provider contract. Procedures were based on the Physician's Current Procedural Terminology Manual Codes (Enclosure F). 
Program administration concerns developed as utilization of podiatric services increased. Numerous issues regarding appropriate provider activities were raised by the provider from the contracts inception. In the absence of definitive guidance the provider began several questionable practices. Self-referrals were $m$ ade in direct conflict with the contract. Charges in excess of negotiated fees were continuously discovered (Enclosure C and $L$ ). Coupons covering the annual deductible were made available to potential patients. Departmental difficulties in monitoring one hundred ninety-one approved procedures were realized. The provider was only scheduled to provide podiatric services one to two days each week. Continuity of inpatient care and risk management, became serious concerns. To compound the problem, the provider treated all eligible patients, including active duty members, one day per week while on active duty as a reservist. An audit of the entire program emphasizing the legal and ethical appropriateness of the provider was ongoing as of June 1986. Payment for completed procedures was also delayed pending completion of an audit by the Office of the Civilian Health and Medical Program of the Uniformed Services. Joint Health Benefits Delivery Program limitations and administrative concerns has prompted McDonald Army Community Hospital to delay further program changes until resolution of current issues and an increase in resources to adequately support the program.

\section{Additional Joint Health Benefits Delivery Program Reviews}

Cutler Army Community Hospital, Fort Devens, Massachusetts initially instituted a Joint Health Benefits Delivery Program with two physiclans for allergy/ears-nose-throat and urology services. Inpatient surgery was generated from urology services. Administrative responsibilities vary based on the facility. Cutler Army Community Hospital elected to change one of the two Civilian Health and Medical Program of the 
Uniformed Services office positions permanently upon activation of the program and the subsequent increase in workload. Health Benefit Advisors trained clinic secretaries and receptionists in locations where Joint Health Benefits Delivery Program providers practiced to issue and complete forms for patients. After the patient was seen by the participating provider and completed the necessary forms, he or she was sent to the Health Benefits Advisor for counseling. Flyers explaining the Joint Health Benefits Delivery Program were in all clinics regardless of participation. Although expected to decrease, Nonavailability Statement issuance did not decrease in the areas where Joint Health Benefits Delivery Program providers were available. Problems in administration and payment authorization have been encountered with the Civilian Health and Medical Program of the Uniformed Services fiscal intermediary. Since the ENT physician was not charging the agreed upon charge, no fee was paid at all by Civilian Health and Medical Program of the Uniformed Services. The physician has since departed. Cost shares paid by patients have not presented a problem thus far. Plans were being $m$ ade to further reduce the program instead of expanding due to Com mand's perception that Joint Health Benefits Delivery Program problems outweighed the benefits derived from it and the absence of a reduction in the overall Civilian Health and Medical Program of the Uniformed Services cost.

Fitzsimons Army Medical Center, Aurora, Colorado had four pediatricians contracted under the Joint Health Benefits Delivery Program. The inpatient pediatric workload has increased due to the addition of the four pedlatricians. Nonavatlability Statements were primarlly issued for cardiology services. Most services were being provided at the Medical Center. After an initial consultation and completion of the physician's portion of the Civillan Health and Medical Program of the Uniformed Services form in the department, patients were briefed by the Health Benefits Advisor who 
assisted in completing the rem ainder of the forms. No particular problems were reported or documented. The Office of the Civilian Health and Medical Program of the Uniformed Services is conveniently located on the grounds of the Medical Center.

Munson Army Community Hospital located at Fort Leavenworth, $\mathrm{K}$ ansas, is a 50-bed acute care hospital. Two surgeons were contracted under the Joint Health Benefits Delivery Program, each served one day per week. Inpatient and ambulatory surgery was performed after eligible patient referrals. No outpatient care was provided. Two General Schedule-7 employees accomplished duttes in the Civilian Health and Medical Program of the Uniformed Services 0ffice. Although the workload increased, no additional resources were allocated for administration of the program. Patients were sent to the Health Benefits Advisor for counseling and presentation of available alternatives. Unlike most facilities reviewed, the Health Benefits Advisor had the physician's fee schedule to make patients aware of the expected cost share amount prior to surgery. After counseling, physicians confirm surgery case(s) with the Health Benefits Advisor. After surgery, the Health Benefits Advisor completes the Civilian Health and Medicai Program of the Uniformed Services form which the physicians sign. Ledgers were being kept on all Joint Health Benefits Delivery Program patients by the surgeons. No plans for program expansion were anticipated.

Joint Health Benefits Delivery Program's have been in effect at Hawley Army Hospital, Fort Benjam in Harrison, for one year. Three general surgeons and one podiatrist were contracted under the program. Verbal approval to expand the program by adding an orthopedist had been recelved. On a non-recurring basis, Joint Health Benefits Delivery Program providers saw active duty patients, but were paid out of supplemental care funds. Civilian Health and Medical Program of the Uniformed Services' workload increased causing another individual to be assigned to assist the Health Benefits Advisor as a 
collateral duty. Participating physicians were negligent in their responsibility to obtain their cost share from the patient. Concom itant problems were a result, specifically, total processing delays. Program expansion was planned although the specialty area had not been identffled.

A 225-bed acute care facility, Reynolds Army Community Hospital is located at Fort Sill, Oklahoma. One ENT provider was operating under the Joint Health Benefits Delivery Program to provide inpatient surgery. Active personnel were also seen under the provisions of a personal services contract. Nonavailability Statement issuance has not decreased since the start of the program; approximately 30 were processed each month. Health Benefits Advisors complete a portion of the Civilian Health and Medical Program of the Uniformed Services form following patient counseling. The physician completes the remainder of the document upon completion of the procedure. Even though a list of procedures and fees were retained by the Health Benefits Advisor, the physician elected to apply the Current Procedural Terminology Manual. Future expansion witl be dependent upon the benefits of the curent program.

The commonaitity in each program review was the lack of planning or plans which anticipated problems experienced. Several programs were initiated prior to any documented plan, utilizing verbal directives instead. Facility or financial limitations and active com $\mathrm{m}$ and involvement consistently prevented adequate Civilian Health and Medical Program of the Uniformed Services office stafiing, information dissem ination and internal program support. Scant or no guidance from the office of the Civilian Health and Medical Program of the Untformed Services yielded lithe in problem resolution or program estabilishment. 
Positively, Joint Health Benefits Delivery Program administrators were attempting to make the program productive through internal coordination with staff and external coordination with fiscal intermediaries, field representatives, $m$ ajor com $m$ ands and the Office of the Civilian Health and Medical Program of the Untformed Services.

1U.S., Department of Defense, Office of the Assistant Secretary of Defense for Health Affairs, Fact Sheet: CHAMPUS Reform Initiative, Septem ber 1985, pp. 1-4.

2U.S., Department of the Army, Untted States Army Health Services Command Biostatistical Activity, Nonavailability Statements Summary for Health Services Comm and, March 1985, pp. T-9. 


\section{PSYCHIATRIC SERVICE}

Kenner Army Community llospital does provide outpatient services, but does not operate an inpatient psychlatric service in accordance with the Mission Authorlzation List (Enclosure 0). The two military psychiatrists currentily assigned to the Medical Department Activity are responsible for providing outpatient services in the community Mental Health Activity. Acute psychiatric patients are perlodically admitted as inpatients into medical beds until stabilized. 140 and 139 nonavailability state ments were issued for psychiatric services in fiscal years 1984 and 1985, respectively, at a cost of $\$ 1,898,732.00$ for 1984 and $\$ 1,787,267$ for 1985 (Enclosure $M$ and $N$ ). Fifty percent of the nonavatlability statements were issued for services provided to adolescents. Civilian Health and Medical Program of the Untformed Services healtr: care summary data categorizes psychiatric services by groups. Group 1 psychiatric codes according to diagnosis are listed in Table 1. Group 2 psychiatric codes are listed in Table 2. Psychiatric diagnoses riot itsted within either psychiatric group are not presently provided for under the Civilian Health and Medical Program of the Untformed Services regulations. 1

\section{Inpatient Psychiatric Service Estim ate}

Staffing requirements, nutrition care, supply expenses, and anticipated equipment needs could be fulfilled for a total first year cost of $\$ 589,279.40$ as reflected in Tables 3 , 4, and 5. An analysis of the data indicates that an inpatient psychiatric ward could be established for an esti $m$ ated cost of $\$ 595,983.40$ the first fiscal year. 
PSYCHIATRY CODES ACCORDINO TO DIAONOSIS

PSYCHIATRY OROUP I (19)

290

291

292

293

294

295

296

297

298

299

300

301

305

309
SENILE AND PRESENILE DEMENTIA

ALCOHOLIC PSYCHOSIS

PSYCHOSIS ASSOCIATED WITH INTRACRANIAL INPECTION

PSYCHOSIS ASSOCIATED WITH OTHER CBREBRAL CONDITIONS

PSYCHOSIS ASSOCIATED WITH OTHER PHYSICAL CONDITIONS

SCHI ZOPHRENIA

ACTIVE PSYCHOSIS

PARANOID STATES

OTHEP. PSYCHOSIS

UNSPECIFIED PSYCHOSIS

NEUROSES

PERSONALITY DISORDERS

PHYSICAL DISORDERS OF PRESUMABLE PSYCHOGENIC ORIGIN

MENTAL DISORDERS NOT SPECIFIED AS PSYCHOTIC ASSOCIATED WITH FHYSICAL CONDITIONS 
26

TABLE 2

PSYCHIATRY CODES ACCORDING TO DIAGNOSIS

PSYCHIATRY QROUP II (20)

302

303

304

306

307

Y13
SEXUAL DEVIATION

ALCOHOLISM

DRUG DEPENDENCE

SPECIAL SYMPTOMS NOT ELSEWHERE CLASSIFIED

TRANSIENT SITUATIONAL DISTURBANCES

SOCIAL MALADJUSTMENT 
TABLE 3

INPATIEAT PSYCHIATRIC WARD STAPRINO BSTIMATE

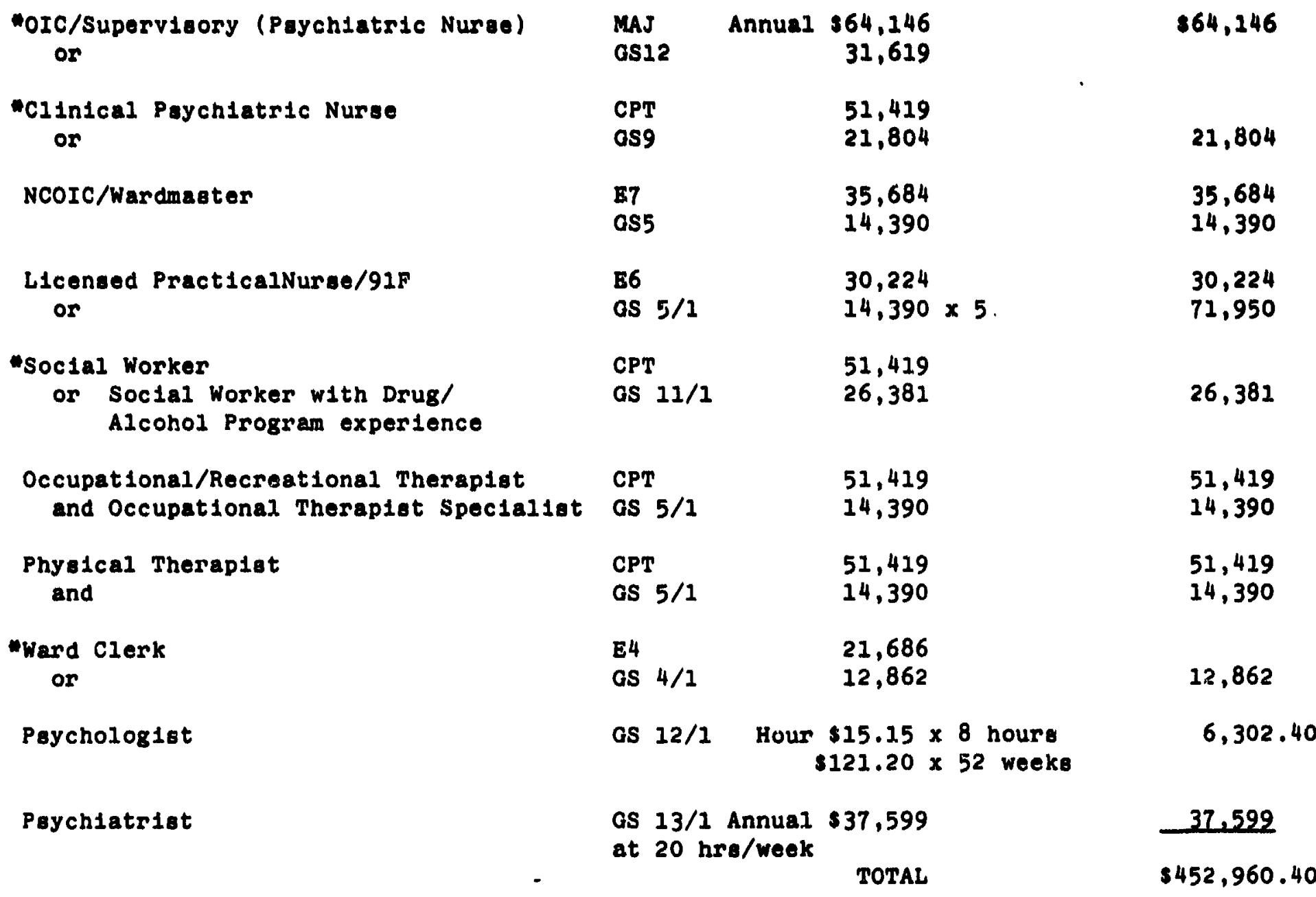

NOTE 1: Civilian annual salaries are based on the grade and first step. M1litary pay 18 based on m1litary otandard composite.

NOTE 2: Staff positions annotated with an asterisk were selected based on Command preference. Civilian staffing was generaliy preferred for continulty of care and minimization of alary costr. 
TABLE 4

BSTIMATED SUPPLY BXPENSES ROR PSYCHIATRIC WARD (PIRST YEAR)

\begin{tabular}{|c|c|}
\hline Linen (Nonconsumable) & $\$ 2,791.00$ \\
\hline Linen (Conoumable) & 900.00 \\
\hline Draperies (Diaposable) & $4,826.00$ \\
\hline $\begin{array}{l}\text { Self Service Supply Center (Admintetrative) } \\
\text { Supplies }\end{array}$ & $1,600.00$ \\
\hline $\begin{array}{l}\text { Miscellaneour (Shelving, Paintinga, Trash } \\
\text { Cans, Blank tapes) }\end{array}$ & $2,800.00$ \\
\hline Medical Suppliea & $1,000.00$ \\
\hline TOTAL & $\$ 19,917.00$ \\
\hline
\end{tabular}

TOTAL

$\$ 19,917.00$ 
TABLE 5

\section{BOUIPKENT GSTIMATE FOR PSYCHIATRIC WARD}

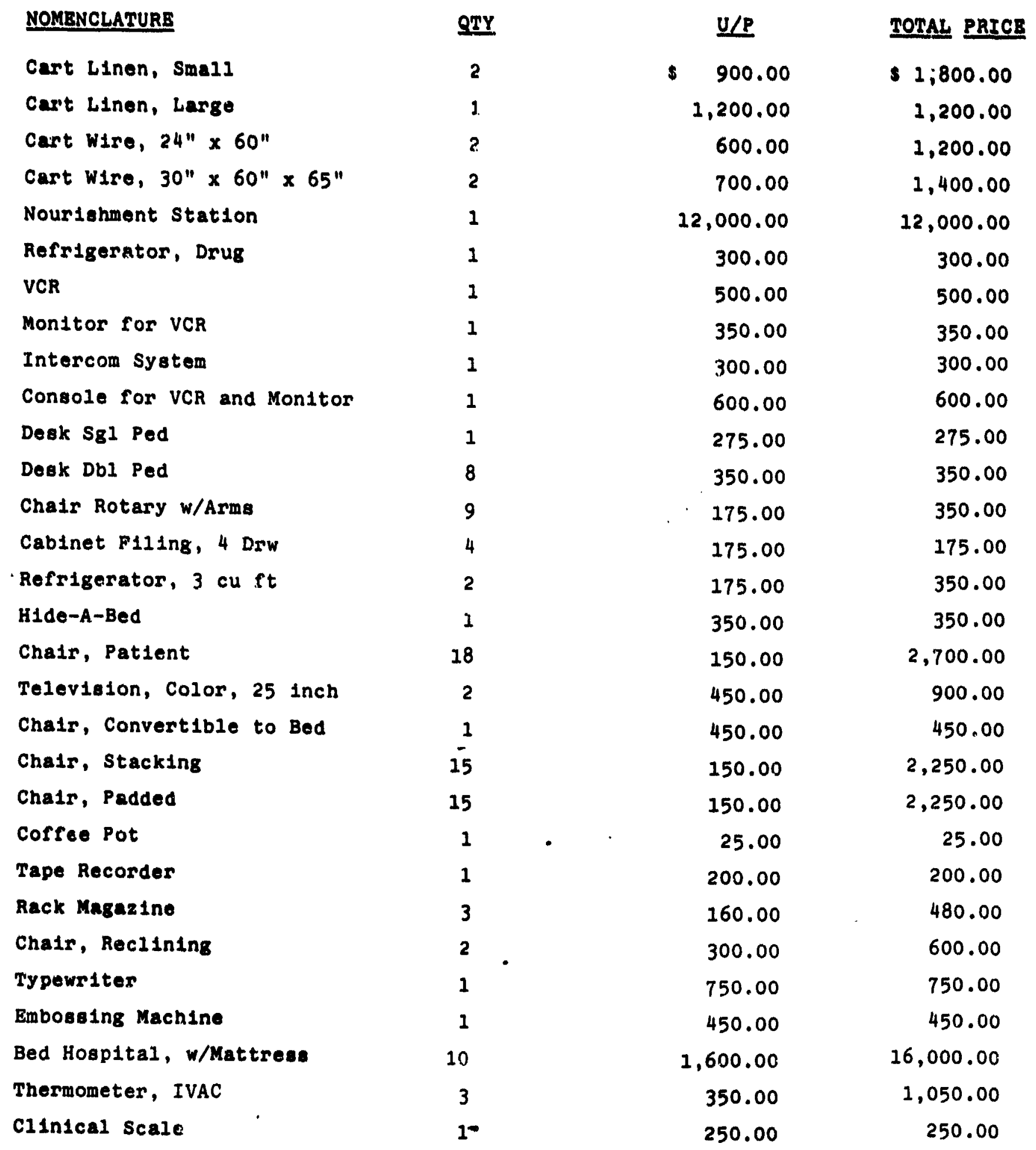


NOMENCLATURE

Lamp, Tabla

Bedalde Cabinet

Overbed Tablo

Cabinet, Medicine

Cart, Chart

Occupational Therapy Arto and Crafts set

Crash Cart, 5 Drawer

Nurse Call System

Conference Room Table

Carpet at $\$ 11.50$ square yard
QTY

5

10

10

1

1

2

1

6

1

$20 \mathrm{yds}$
$\underline{U / P}$

$\$ \quad 75.00$

120.00

150.00

660.00

300.00

95.00

850.00

$5,200.00$

500.00

11.50

TOTAL
TOMAL PRICE

s $\quad 375.00$

$1,200.00$

$1,500.00$

660.00

300.00

180.00

850.00

$31,200.00$

500.00

230.00

$\$ 86,850.00$

NOTE: Equipment estimates were provided by the Logistics Division. 
The estimated costs of physically transforming the available ward into an inpatient psychiatric ward are shown in Table 6. Costs were based on historical Civilian Health and Medical Program of the Uniformed Services workload, actual personnel costs and estim ated logistical requitements. Fixed costs and avaflable costs, particularly base support engineer and logistical services were not maintained in a manner which permitted an estim ation of Kenner Arm y Com munity Hospital costs.

\section{Special Considerations}

Inpatient psychiatric services traditionally requtre large numbers of trained personnel to provide quality services as compared to other inpatient services, such as medical-surgical wards, which conversely have more equipment requirements. ${ }^{2}$ According to the Deputy Commander for Clinical Services at Kenner Army Community Hospital, several administrators and practitioners in area psychiatric hospitals and the literature, the baseline services that should be provided in a ten-bed psychiatric $w$ ard are psychological testing, social work services, drug and alcohol rehabilitation services, psychotherapy, psychometrics and general psychlatry. Customary ancillary services include radiological, laboratory, electrocardiogram, electroencephlogram and pharm aceutical services. 3

Civilian Health and Medical Program of the Uniformed Services policies provide directives regarding the $1 \mathrm{~m}$ itations of inpatient mental health care. Conditions which are covered by Civilian Health and Medical Program of the Uniformed Services include attention deficit disorders, spectfic developmental disorders, collateral visits which are defined as services to interpret or explain results of psychiatric, other medical examinations and procedures, other accumulated data to family or other responsible persons, or advising them on how to assist the patient. ${ }^{4}$ Psychotherapy, crisis 


\section{RENOVATION COST ESTIMATE FOR INPATIENT}

\section{PSYCHIATRIC WARD}

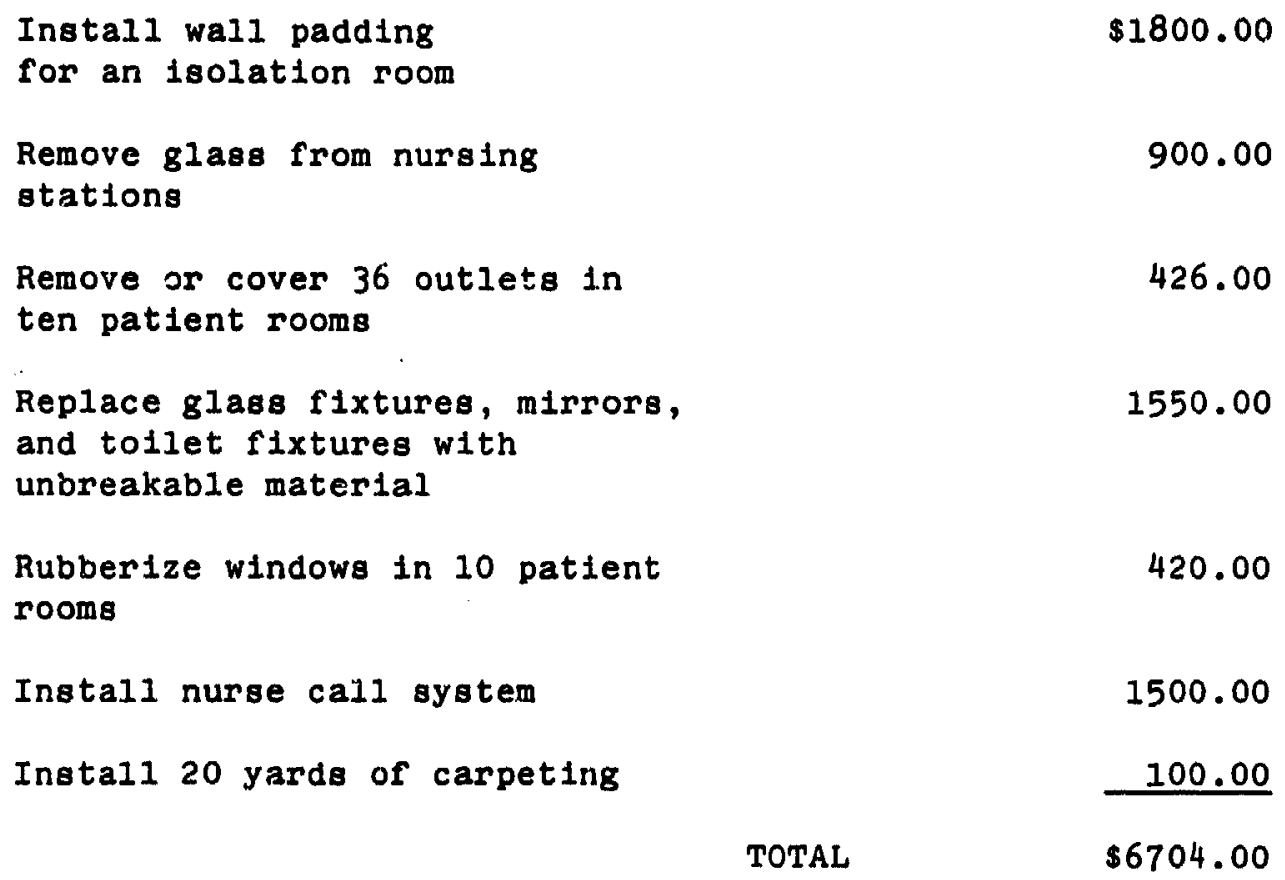


intervention, social work services, and drug and alcohol rehabilitation are also reimburseable under the Civilian Health and Medical Program of the Untformed Services program.

Restrictions on inpatient mental health care do exist in the Civilian Health and Medical Program of the Uniformed Services program. Inpatient admissions beginning on or after January 1, 1983, perm it no Civilian Health and Medical Program of the Uniformed Services funds to be used for payment of institutional or professional claims for inpatient mental health services in excess of sixty days in a calendar year. The limit does not apply to the following circumstances however:

a. Any services provided under the Program for the handicapped or in a residential treatmient center.

b. Any services provided as partial hospitalization, if such services are covered by Civilian Health and Medical Program of the Uniformed Services.

c. Any inpatient mental health services rendered to patients admitted before January 1, 1983, provided the patient rem ains continuously hospitalized and the inpatient care is medically or psychologically necessary.

d. Inpatient services beyond sixty days are covered if the Director, Civilian Health and Medical Program of the Uniformed Services, finds that the patient is suffering from an acute mental disorder or acute exacerbation of a chronic mental disorder which results in the patient being put at significant risk to self or a danger to others and the patient requires a type, level, and intensity of service that can only be provided in an inpatient setting.

e. The patient has medical complications and requires a type, level, and intensity of service that can only be provided in an inpatient setting. 
f. Psychotherapy incidentai to a rehabilitation stay for accident victims or a medical stay for cancer patients when the therapy is not intensive or on-going and does not contribute to the need for an inpatient stay. 5

\section{Comparison of Civilian Heaith and Medical Program of the Uniformed Services} and Joint Health Benefits Delivery Program Psychiatric Service Costs

Civilian Heaith and Medical Program of the Uniformed Services Health Care Sum $m$ ary by prim ary diagnosis data segregates inpatient and outpatient costs by diagnosis for fiscal years 1984 and 1985. The primary area where substantial savings could be experienced utilizing the Joint Health Benefits Delivery Program instead of the standard Civilian Health and Medical Program of the Uniformed Services method was in total government inpatient and professional costs (Enclosures $M$ and $N$ ). Significant savings could also be realized for inpatient professional and outpatient services since patients would not be charged for ancillary services as required when care was rendered in a civilian facility. Joint Health Benefits Delivery Program estimated costs and Civilian Health and Medical Program of the Uniformed Services inpatient costs for fiscal years 1984 and 1985 were compared for determ ination of the most cost effective and efficient program. Itenization of actual Civilian Health and Medical Program of the Uniformed Services and calculated Joint Health Benefits Delivery Program for fiscal years 1984 and 1985 inpatient costs are as indicated in Table 7. 
TABLE 7

CIVILIAN HEALTH AND MEDICAL PROGRAM OF THE UNIFOR MED SERVICES AND JOINT HEALTH BENEFITS DELIVER Y PROGRAM PSYCHIATRY SERVICE COSTS FOR FISCAL YEARS 1984 and 1985

Civilian Health and Medical Program of the Uniformed Services Fiscal Year 1984

$\begin{array}{cccc}\text { Psychiatry } & \text { Psychiatry } & \text { Beneficiaries } & \text { Beneficiaries } \\ \text { Group 1 } & \text { Group 2 } & \text { Group 1 } & \text { Group 2 }\end{array}$

Total Inpatient

Hospital Services

$\$ 990,120$

$522,041=\$ 1,512,161$

92

$48=140$

Inpacient Hospi-

ta1 Services

Government

Cost (75\%)

732,311

$421,654=\$ 1,153,965$

Inpatient Hospl-

tal Services

Patient Cost

(25\%)

257,809

$100,387=358,196.00$

A verage Length of

Stay (Days)

32.53

43.45

Total 0ccupled

Bed Days

3,123

$1,912=5,035$

Total Inpatient

Professional

Services Cost

110,353

47,439

82

46

Total Government

Cost

$89,391 \quad 35,047$

Total Patient

Cost

$20,962 \quad 12,392$

Kenner Army Com munity Hospital Joint Health Benefits Delivery Program Cost

Total Psychia-

tric Inpatient

Costs

199,664

Occupied Bed

$D$ ays

Cost Per Bed

Day 
Kenner Army Communtty Hospital Rate applied to Civilian Health and Medical Program of the Untformed Services Inpatient Hospital Services Government Cost of $\$ 1,512,161.00$

\author{
5035 Occupied Bed Pays for 140 patients \\ $x \quad 250.51$ cost per bed day \\ $\$ 1,261,317.00$
}

$\$ 1,512,161.00-1,261,317.00=\$ 250,844,00$ (Savings Potential)

CIVILIAN HEALTH AND MEDICAL PROGRAM OF THE UNIF ORMED SERVICES PSY CHIATRIC CHARGES (F OR FISCAL. YEAR 1985)

$\begin{array}{ccll}\text { Psychlatry } & \text { Psychiatry } & \text { Group 1 } & \text { Group 2 } \\ \text { Group 1 } & \text { Group 1 } & \text { Beneficiaries } & \text { Beneficiaries }\end{array}$

Total Inpatient

Hospital Services

$\$ 1,035,054+$

$384,881=1,419,935$

101

Inpatient Hospital Services

Government

Cost

748,100

272,228

Inpatient Hospi-

tal Services

Patient Cost

286,954

111,653

A verage Length of

Stay (D ays) $\quad 30.23$

25.29

Total Occupied Bed

Days

$3,325+$

$1,062=4387$

Total Inpatient

Professional

Services Cost

$93,754+$

$45,894=139,648.00$

Total Government Cost

75,327

29,962

Total Patient Cost

18,427

15,932 
Kenier Army Com munity Hospital Joint Health Benefits Delivery Program Cost

Total Psychiatric

Inpatient Cost 223,148

Occupled Bed Days 1125

Cost Per Bed Day 198.35

Kenner Army Com munity Hospital Cost Applied to Civilian Health and Medical

Program of the Untformed Services Inpatient Hospital Services Govern ment Cost of $\$ 1,419.935$

4387 0ccupied bed days for 139 patients

$\underline{x 198.35}$ cost per bed day

$\$ 870,161.45$

$\$ 1,419,935-\$ 870,161.45=\$ 549,773.6$ (Savings potential) 
Kenner Army Community Hospital data was retrieved from the Comptroller Division's Uniform Chart of Accounts historical Medical Expense Performance Report. The Civilian Health and Medical Program of the Uniformed Services fiscal year 1984 total psychiatric inpatient hospital cost was $\$ 1,512,161.00$ versus a Joint Health Benefits Delivery Program estimated cost of $\$ 1,261,317.00$, resulting ina $\$ 250,844.00$ Civilian Health and Medical Program of the Unfformed Services potential net expenditure difference or savings. Kenner Army Community Hospital's cost per occupied bed day rates were based on an average cost. In accordance with the military's current cost accounting policies, patient bed days for any diagnosis were not distinguishable as were the costs in civilian hospitals under diagnosis related groups. Psychiatric hospitals, or hospitals with psychiatric wards, use accounting practices which establish charges based on type and amount of care received, overhead, and a revenue generating charge. For example, a surgical patient's occupied bed day rate would be identical to the rate for a patient admitted for influenza during the same fiscal year. Inpatient professional hospital psychiatric services were rendered for a total Civilian Health and Medical Program of the Untformed Services cost of $\$ 157,792.00$ for fiscal year 1984 and $\$ 139,648.00$ for fiscal year 1985. Under the Joint Health Benefits Delivery Program, savings could be realized in professional services for the patient and the government. Joint Health Benefits Delivery Program providers must negotiate a fee schedule (with the Office of the Civilian Health and Medical Program of the Uniformed Services) for spectfled procedures prior to signing a contract with the Hospital Com mander. Professional service fees have been lower for providers rendering care under the Joint Health Benefits Delivery Program in military facilities since overhead expenses, such as administrative, clerical, paraprofessionals, supplies, pharmaceuticals, physical therapy, radiology, and laboratory services, were avallable at no additional cost to the provider or patient. 6 Total Civilian Health and 
Medical Program of the Untformed Services inpatient professional hospital psychiatric services charges for fiscal years 1984 and 1985 could have been reduced by those assoclated charges. The total charge could have been reduced by the minimum $\$ 25.00$ fee charged each patient when services were recelved in a civilian medical treatment fachity. There was no yearly deductible or $\$ 25.00$ minimum fee for care received in a miltary medical treatment facility. Subsistence and professional service rates were based on beneficiary status excluding the deductible and minimum service fee. Civilian Health and Medical Program of the Uniformed Services rates include a deductible requirement and minimum fee based on beneftciary category.

1U.S., Department of Defense CHAMPUS, CHAMPUS Policy Manuai, Volume II, June 1984, pp 1-5.

2U.S., Department of Defense CHAMPUS, CHAMPUS Policy Manual, Volume I, Decem ber, 1982, pp. 12-20.

3Virginia. Virginia Health Services Cost Review Commission, Interpretation and Findings: Comparison of Hospital Charges as of February 1, 1985 and Compartson of Hospital Charges by Diagnoses for the Month of February $1985, \mathrm{pp} .15-20$.

4U.S., Department of Defense CHAMPUS, CHAMPUS Policy Manual, Volume In, June 1984, pp. 6-8.

5ibid.

6U.S., Department of the Arm y Headquarters, United States Army Health Services Com $\mathrm{m}$ and, Implementation of Joint Health Beneftts Delivery Program, June, 1984, pp. 2-5. 
IV. OBSTETRICS SERVICE

Both inpatient and outpatient obstetrical services were discontinued at Kenner Army Com munfty Hospital in 1976. Upon determ ination of pregnancy in the Kenner Army Com munity Hospital Gynecology Clinic or in a civifian factitty, patients were im medfately referred to the Health Beneftts Advisor for Civilian Health and Medical Program of the Untformed Services benefits counseling and to request a Statement of Nonavallabtitty (Appendix P). Pregnant patients experiencing i.snpregnancy related illnesses, such as orthopedic injurles, were infrequently admftted to Kenner Army Community Hospital during fiscal years 1984 and 1985.

\section{Inpatient Obstetric Service Estim ate}

Inpatient obstetrical services for fiscal years 1984 and 1985 were provided under Civilian Health and Medical Program of the Untformed Services for a cost of \$1,381,275.00 and $\$ 1,484,095.00$, respectively. Estim ated costs for transforming the avaflable ward into an inpatient obstetrical ward, nursery and labor and defivery sutte ts shown in Table 8. Costs were based on historical Civifian Health and Medical Program of the Untformed Services workload, actual personnel costs and estimated logistical requirements. Base support engineer and loglstical costs were not separated for estim ation of overan base support expenses. Ward renovation, personnel, supplies and equipment acquisttion could be accomplished for a frost year cost of \$1,016,702.00 (Table 8 and 9). Inpatient obstetrical and nursery services could result in an increased inpatient pediatric 
TABLE 8

\section{ESTIMATED SUPPLY EXPENSES FOR OBSTETRICS}

\section{Supply Exponses}

Linen (Nonconsumable)

Linen (Consumable)

$\$ 2,792$

900

Draperies (Disposable)

SSSC (Administration)

4,826

800

Misc (Desks, Shelving, Trash cans)

1,500

Medical Suppliea

10,000

TOTAL

$\$ 20,817$

Ward Renovation Expenseg

Ward Upgrade

Paint Ward

Replace Glass

$\$ 9,800$

1,500

2,800

Renovate Nurse Call

5,500

TOTAL

$\$ 39,800$

OB STAFFING

\section{LABOR/DELIVERY/POST PARTUM}

Clinical head Nurse

Clinical Nurse

Wardmaster

Licensed Practical Nurse

NURSERY

Clinical Nurse

Licensed Practical Nurse

TOTAL

$\frac{\text { RANK/ }}{\underline{\text { GRADE }}} \quad \frac{\text { NO. OF }}{\text { POSNS } x} \quad \frac{\text { YEARLY }}{\text { SALARY }}=$

MAJ $11 \$ 66,137$

GS-09 624,712

E7 1137,241

$\begin{array}{lll}\text { GS-05 } & 5 & 16,310\end{array}$

as-09

GS-05

5

5

24,712

16,310

23

\section{SALARY}

$\$ 66,137$ 148,272 37,241 81,550

123,560 81,550

$\$ 538,310$

NOTE: FY 85 Composite Standard Rate for Military and FY85 GS Pay Scale, Step 5 for Cvili Service. 
TABLE 9

EQUIPUERNT ESTIMATE FOR OBSTETRICS WARD

\begin{tabular}{|c|c|c|c|c|}
\hline NOMENCLATURE & QTYY & & $\underline{\mathrm{U} / \mathrm{P}}$ & TOTAL PRICE \\
\hline Cart LInen, Small & 2 & & 900.00 & $1,800.00$ \\
\hline Cart Linen, Large & 1 & & $1,200.00$ & $1,200.00$ \\
\hline Cart Wire, 2"4" $\times 60 "$ & 2 & & 600.00 & $1,200.00$ \\
\hline Cart W1re, $30 " \times 60 " \times 65 "$ & 2 & & 700.00 & $1,400.00$ \\
\hline Nourishment Station & 1 & & $12,000.00$ & $12,000,00$ \\
\hline Refrigerator, Drug & 1 & & 300.00 & 300.00 \\
\hline $\mathrm{VCR}$ & 2 & & 500.00 & 500.00 \\
\hline Monitor for VCR & 1 & & 350.00 & 350.00 \\
\hline Intercom System & 1 & & 300.00 & 300.00 \\
\hline Console for VCR \& Monitor & 1 & & 600.00 & 600.00 \\
\hline Desk Sgl Ped & 1 & & 275.00 & 275.00 \\
\hline Desk Dbl Ped & 1 & & 350.00 & 350.00 \\
\hline Cha1r Rotary W/Arms & 2 & & 175.00 & 350.00 \\
\hline Cabinet, Filing, 4 Drawer & 1 & & 175.00 & 175.00 \\
\hline Refrigerator, $3 \mathrm{cu} \mathrm{ft}$ & 2 & & 175.00 & 350.00 \\
\hline H1de-A-Bed & 1 & & 350.00 & 350.00 \\
\hline Chair, Patient & 18 & & 150.00 & $2,700.00$ \\
\hline Chatr, Rocking & 10 & & 175.00 & $1,750.00$ \\
\hline Cha1r, Convertible to Bed & 1 & & 450.00 & 450.00 \\
\hline Cha1r, stacking & 15 & & 150.00 & $2,250.00$ \\
\hline $\begin{array}{l}\text { Chest of Drawers for Birthing } \\
\text { Room }\end{array}$ & 2 & & 250.00 & 500.00 \\
\hline Rack Magazine & 3 & . & 160.00 & 480.00 \\
\hline Chair, Recilning & 2 & & 300.00 & 600.00 \\
\hline Ty pewriter & 1 & & 750.00 & 750.00 \\
\hline Embossing Machine & 1 & & 450.00 & 450.00 \\
\hline Televioion & 8 & & 350.00 & $2,800.00$ \\
\hline Bed Hospltal, w/Mattress & 10 & & $1,600.00$ & $16,000.00$ \\
\hline Anesthesia Apparatus & 1 & & $12,000.00$ & $12,000.00$ \\
\hline $\begin{array}{l}\text { Sphygmomanometer Electronic- } \\
\text { U1trasonic }\end{array}$ & 2 & & $2,000.00$ & $4,000.00$ \\
\hline Thermometer IVAC & 3 & & 350.00 & $1,050.00$ \\
\hline
\end{tabular}


NONBNCLATURB

Fotal Resurcitation Unit

Delivery Table

Clintcal scale

Surgical Lights

Bedside Cabinet

Overbed Table

Washer Ster111zer

Warming Cabinet

Portable Ultrasound

B1rthchatr/Ch1ld Bearing Bed

PH Monitor

Pocket Dopler

Antepartum Fotal Monitor

Fetal Mon1tor Labor Room

Central system

220 PH System

U1 trasound Scanner

Intubator Infant

Incubator Infant, Transport

Neonatal Intensive Care Center

Hospital Call System

Monitor Oxygen

Monitor Respiration System

Heating Unit Free Standing

Suction Apparatus

Stool, Adjustable

Baseinet Warning Cart

Bassinet Warming w/Cabinet

Crauh Cart, 5 Drawer

Cabinet Surgical Instrument

Cabinet Medicine

Cart Chart

Light Surgical Floor

Table, Exam

Light, B111rubin

B111meter
$\underline{U / P}$

TOTAL PRICE

s $8,950.00$

$11,000.00$

250.00

$1,500.00$

120.00

150.00

$20,000.00$

$4,000.00$

$12,000.00$

$7,000.00$

$6,000.00$

500.00

$12,000.00$

$11,160.00$

$5,500.00$

$19,000.00$

$6,500.00$

$6,300.00$

$15,000.00$

$5,200.00$

$1,100.00$

$8,600.00$

4,000.00

400.00

350.00

$3,500.00$

450.00

850.00

900.00

660.00

300.00

800.00

$1,200.00$

$2,500.00$

$1,200.00$

GRAND TOTAL
$8,950.00$

$22,000.00$

250.00

$3,000.00$

$1,320.00$

$1,650.00$

$20,000.00$

$4,000.00$

$12,000.00$

$42,000.00$

$6,000.00$

$1,000.00$

$12,000.00$

$33,480.00$

$20,885.00$

$5,500.00$

$19,000.00$

$13,000.00$

$6,300.00$

$15,000.00$

$31,200.00$

$1,100.00$

$8,600.00$

4,000.00

400.00

$1,750.00$

$7,000.00$

$7,200.00$

850.00

900.00

660.00

300.00

$1,600.00$

$1,200.00$

$2,500.00$

$1,200.00$ 
population. Pediatric inpatient services were not routinely provided at Kenner Army Community Hospltal. Acutely ill or uncomplicated orthopedic patlents were perfodically admitted to the hospital. Increased requirements for inpatient pediatrics would require examination and estimation of obstetrical services were to be re-established in the hospital.

\section{Civilian Health and Medical Program of the Uniformed Services}

\section{Maternity Care Provisions}

Civilian Health and Medical Program of the Uniformed Services maternity care benefits begin when the beneficiary becomes pregnant, continues through delivery and up to the first six weeks after the baby is born.1 Maternity care is defined as care needed due to pregnancy including complications from pregnancy. Treatment of nonpregnancy related conditions such as a broken leg are not covered under Civilian Health and Medical Program of the Uniformed Services maternity care benefits. Civilian Health and Medical Program of the Uniformed Services maternity care costs are cost shared by the beneficiary. The amount is determined by the frequency of care, the status of the beneficiary, and whether the baby is delivered in an inpatient or outpatient setting.

All women eligible for Civilian Health and Medical Program of the Uniformed Services benefits are eligible for maternity care under Civilian Health and Medical Program of the Uniformed Services. This includes spouses and unmarried children of active duty members, retirees, spouses of retirees and their unmarried children and the spouses and unm arried children of deceased active duty and retired service members.

Special provisions of the Civilian Health and Medical Program of the Uniformed Services prograni should be understood prior to utilization of maternity benefits to avoid 
nonreimbursement of services or other cost sharing dilemmas. Circumstances may require $m$ ore than one pregnancy-related $a d m$ ission during the $m$ aternity birth episode. In this case, all admissions are considered to be a single admission for cost-sharing purposes, regardless of the number of days between admissions, even when the beneficiary is admitted to more than one hospital.2 Only Civilian Health and Medical Program of the Uniformed Services-approved birthing centers can be uttlized when Civilian Health and Medical Program of the Uniformed Services "cost shares" the delivery and maternity care fees on an inpatient basis. Although military health care facilities are not permitted to refer patients to a particular organization, some hospitals provide listings of supplemental health insurance plans to assist beneficiaries who must fulfith "cost sharing" requirements (Appendix Q). Beneficiarles planning to deliver at home must receive a Nonavailability Statement prior to going to the hospital if home delivery complications arise. Prescription drugs related to the maternity episode are payable on an inpatient or outpatient basis depending on the status of the patient at the time of defivery or other termination of pregnancy (e.g., $m$ iscarriage). However, prescription drugs provided on an outpatient basis which are not directly related to the obstetrical care would be "cost shared" on an outpatient basis even though administered during the maternity episode. 3 Under normal circumstances no separate "cost share" would be collected for the newborn as the newborn is not considered a separate admission, but is included in the mother's admission. Problems are created in some states which have refmbursement programs which require hospitais to bill newborn charges separately from the mother's charge. ${ }^{4}$ The Civilian Health and Medical Program of the Unfformed Services permits processing of the bill with special attention paid to ensure no duplication of the mother's charges or fees beyond the care received during the $m$ other's admission. 
Compartson of Civiltan Health and Medical Program of the Untformed Services and Joint Health Benefits Delivery Program Obstetrical Service Costs

Obstetrical services for fiscal year 1984 were provided at a Civilian Health and Medical Program of the Uniformed Service calculated cost of $\$ 1,396,601$. The cost included inpatient hospital services, inpatient professional services, outpatient professional services and outpatient care "cost shared" as an inpatient. Total government and patient cost for inpatient services was $\$ 1,381,276$. Outpatient services were provided at a cost of $\$ 15,325$ (Appendix M). Inpatient services provide the greatest opportunity for overall cost savings under the Joint Health Beneftts Delivery Program. The following represents a comparison of the Civilian Health and Medical Program of the Uniformed Service and calculated Joint Health Benefits Delivery Program obstetrical service costs for inpatient services:

CIVILIAN HEALTH AND MEDICAL PROGRAM OF THE UNIFORMED SERVICES OBSTETRICS CHARGES

$\begin{array}{cccc}1984 & 1984 & 1985 & 1985 \\ \text { Obstetrics } & \text { Beneficiaries } & \text { Obstetrics } & \text { Beneficiaries }\end{array}$

Total Inpatient Hospital Services

$\$ 958,242$

411

$1,014,532$

412

Inpatient Hospi-

tal Services

Government Cost 907,279

941,168

Inpatient Hospital

Services $P$ atient

Cost

50,963

73,364

Average Length of Stay (Days)

Total Occupied Bed Days 
Total Inpatient

Professional Services

Cost $\quad 423,035$

469,563

Total Government

Cost $\quad 409,196$

442,165

Total P atlent

Cost

13,839

27,398

Kenner Army Com munity Hospital Joint Health Benefits Delivery Program Cost

Kenner Army Com munity Hospital cost applied to the Civilian Health and Medical

Program of the Untformed Services Inpatient Hospital Services Governm ent Cost

for fiscal year 1984 and \$1,014,532, for Fiscal year 1985.

Occupied Bed Days for 411 maternity patients

Cost per bed day for fiscal year 1984

250.51

$490,749.09$

$\$ 958.272 .-\$ 490,749.09=\$ 467,462.91$ (Savings Potential)

Occupied bed days for 412 m aternity patients

Cost per bed day for fiscal year 1985

198.35

$\$ 349,889.40$

$\$ 1,014,532$. $-\$ 349,889.40=\$ 664,642.60$ (Savings Potential)

A potential savings of over one million dollars was reflected in the comparison of Kenner Army Communtty Hospital and Civflian Health and Medical Program of the Uniformed Services costs. An average cost per bed rate was utilized to estim ate the cost of services provided at Kenner Army Community Hospttal. Again, the milttary's cost accounting policies do not distinguish patient charges by diagnosis as do civilian medical treatment factlities. Inpatient professional hospital obstetrical services were provided at a fiscal year 1984 Civilian Health and Medical Program of the Uniformed Services cost of $\$ 958,212.00$ and a 1985 cost of $\$ 1,014,532.00$. The significant difference in Civilian Health 
and Medical Program of the Uniformed Services and Kenner Army Community Hospital costs $m$ ay be partially attributed to several factors, one of which $w$ as the absence of the advantage derived from Civilian Health and Medical Program of the Uriformed Services negotiated professional fee schedule with providers contracted under the Joint Health Benefits Delivery Program. As previously discussed, charges received for care provided in a military medical treatment facility would not include ancillary service fees, annual deductibles, or supply costs. Additional savings could be realized for inpatient professional services based on decreased provider overhead. The $\$ 25.00 \mathrm{minimum}$ fee wouid be avoided when care is provided in a military treatment factilty. Civilian Hea?th and Medical Program of the Uniformed Services charges reflected in fiscal years 1984 and 1985 Health Care Summaries include an annual deductible and minimum fee charge (Appendix $M$ and $N$ ).

1 U.S., Department of Defense, CHAMPUS Maternity Care, CHAMPUS FS-8, Aurora, Colorado, 1985, pp. 1-4.

2Ibid., p.2.

3Ibid., p.3.

4 Ibid., p.4. 


\section{$\because$ CIVILIAN HEALTH AND MEDICAL PROGRAM OF THE UNIFORMED}

\section{SER VICES REFORM INITIATIVES}

Aithough the emphasis of the feasibility study was to determ ine whether obstetrical or psychiatric services should be recom mended for implementation under the Joint Health Benefits Delivery Program utilizing fiscal years 1984-1985, a realistic recommendation could not be made without a discussion of external factors which would significantly affect the recoin mendations. Since the Joint Health Benefits Delivery Program operates under the Civiliar, itealth and Medical Program of the Unfformed Services regulation, Civilian Health and Medical Program of the Uniformed Services' reform initiatives represent a critical external factor that should be considered as a realistic part of the feasibility study.

The Civilian Health and Medical Program of the Uniformed Service reform Initiative is designed to address several serious problems in the milftary health services system. Currently, the Civilian Health and Medical Program of the Untformed Services program is too complex and too costly, both for the government and for beneficiaries. The primary mission of the military health services system ts to be ready to care for active duty forces in time of war. In peacetime, the system provides health care to 2.2 mithion active duty members and 7.6 million dependents, retired members, their families and survivors. 1 Military medical facilties handle one millicn admissions and fifty million outpatient visits per year. In addttion to tts 168 hospitals and over 300 medical clinics, the Department of Defense (DOD) operates Civilian Health and Medical Program of the Untformed Services which pay: for a portion of the care with beneficiary "cost sharing" proyistons. Now operated as a fee-for service program, Civilian Health and Medical 
Program of the Untformed Services is estimated to cost 1.5 btllion dollars in fiscal year 1986.2 Many military hospitais are overloaded, particularly for outpatient care, causing long delays in obtaining appoint ments even with the introduction of new programs such as the Joint Health Benefits Delivery Program. Reform plans aim to address these problems by adopting innovations like thuse that have made private sector health programs less costly and complex, such as health matntenance organizations and preferred provider organizations. 3 Substantially increasing access to free primary care outpatient care, reducing beneficiary cost sharing amounts, control of government costs, and increasing the ability of military hospitals to provide specialty and inpatient services, particularly those related to wartime medical and surgical specialty needs, are also Civilian Health and Medical Program of the Uniformed Service reform objectives.

Reduction of Beneficiary Costs Under Civilian Health and Medical Program of the Uniform ed Services

The Civilian Health and Medical Program of the Uniformed Services' program currently operates as a bill-paying agency. It has made no attempt to use its nationwide buying power for the advantage of $D O D$ beneficiaries, as is the practice in $m$ any private sector health care agencies and the Army Medical Department's supply system.4 As a result, Civilian Health and Medical Program of the Uniformed Services costs have risen faster than private sector health care costs and DoD beneficiaries who recelve care in the civilian conmunity must frequently pay substantial out-of-pocket costs under the copayment requirements of the program. Department of Defense is now seeking to use its nationwide buying power by establishing three regional contracts covering the United States. Current planning is focused on awarding three regional contracts covering the entire United States under which competitively selected contractors would assume the 
financial risk for any care provided to non-active duty beneficlaries in the civilian sector. For a fixed sum, the contractors would become responstble for paying for health care received by Department of Defense beneficiaries from civilian sector providers. This arrangement differs from the Joint Health Benefits Delivery Program in that the Joint Health Benefits Delivery Program is a fee-for-service program and the Civilian Health and Medical Program of the Uniformed Services reform initiative proposes a more cost effective capitation based program. Because the contracts would be financially at risk for care provided in the civilian sector they should have the incentive to organize high quality, cost effective civilian hospitals and physicians into preferred provider networks, with an emphasis on primary care that will offer services to Department of Defense beneficiaries at reduced costs. Specific quality of care requirements that are not presently possible under the current Civilian Health and Medical Program of the Uniformed Services regulations would also be a part of the contract with the "at risk" contractor. Contracts will not be required to be aw arded on the basis of low bid. Civilian Health and Medical Program of the Uniformed Service program savings that can be gained by adopting cost-effectiveness reforms that have worked in the civilian sector will be returned to beneficiaries in the form of reduced Civilian Health and Medical Program of the Uniformed Services copaym ent requirements. 5

\section{Increase Access to Prim ary Care}

A mong the most significant improvements for beneficiaries that may be made possible by adoption of Civilian Health and Medical Program of the Uniformed Services reforms is increased access to primary care. Currently, a leading source of beneficiary dissatisfaction are the long delays experienced in obtaining appointments at mflitary 
health treatment factlties. Civitian Health and Medical Program of the Untformed Services reform plans to address the access issue by requiring the contractor to establish free primary care centers to Department of Defense beneficiaries throughout the United States. Medical specialties that are planned for the centers include, but are not lim fted to, pediatrics, gynecology, internal medicine and family practice. Services not presently paid by Civilian Health and Medical Program of the Uniformed Services, such as routine physical examinations and preventive care, are also included in the reform package. Once established, the primary care centers will also serve as centers for referrat of beneficiaries who require specialty services or inpatient treatment to military hospitals, or to civilian hospitals if care is not available. Patients would only be referred to those civilian hospitals that are part of the regional contractor's preferred provider network unless the service is unavallable. Preferred provider network facilities would offer services to beneficiaries at a reduced cost. 6

Increased Access to Military Hospitals for Inpatient Care

The proposed Civilian Health and Medical Program of the Uniformed Services reform initiatives is expected to assist military hospitals in taking steps to increase the availability of inpatient care. 7 Beneficiaries must now obtain expensive specialty and inpatient services in the civilian community and comply with copayment requirements. The copayment requirements of the Joint Health Benefits Delivery Program are not as extensive, but can still represent an appreciable amount for beneficiaries. Reduction of the dem and for primary care at $m$ ilitary should allow the shifting of personnel to inpatient or other services. In addition, the regional contractor would be required to supplement milftary staff by supplying civilian physicians to the military hospital when needed to meet the dem and for spectalty care and inpatient services. 
Overall Outcome and Impact of the Civilian Health and Medical Program of the Untformed Services Reform Plan on the Joint Health Benefits Dellvery Program

Aithough the simplification of Civilian Health and Medical Program of the Untformed Services procedures has been attempted previously no favorable results have been realized according to the administrators of the Civilian Health and Medical Program of the Uniformed Services and Department. of Defense. 8 The current system is complicated and time-consuming. It requtres beneficiaries to pay physicians directly or with supplemental care policies prior to seeking Civilian Health and Medical Program of the Untformed Services reimbursement, only to experience burdensome delays (Appendix $R)$. Under the proposed system, physicians in the preferred provider network would not require beneficiaries to process claims or $m$ ake substantial prepay or copaym ents.

According to the Civilian Health and Medical Program of the Uniformed Services, requirements are likely to include no reduction in the current Civilian Health and Medical Program of the Uniformed Services benefits package; reduced out-of-pocket expenditures by beneficiaries; preservation of beneficiary freedom to select other than the preferred provider without reduced copayments; assumption by the contractor of current Civilian Health and Medical Program of the Unfformed Service fiscal intermediary functions; acceptance of quality assurance standards and credentialing procedures; and staff sharing arrangements to $m$ aximize efficiency in both $m$ ilitary and preferred provider facilities.

The reduction of serious deficiencies in medtcal readiness is another outcome that is expected upon the execution of the reform plan. Currently, only about one-third of the surgeons needed to care for combat casualties are in the Department of Defense health care system. Improved and increased use of civilian physicians and other medical personnel should assist in assuring that the necessary priority is given to acquiring the 
approprlate numbers of military medical personnel in the specialties that would be needed to im prove wartime readiness. Im proved access for benefictaries during peacetime should also be realized as sources of care both in the military and civilitan com m untty increase. 9

Currently, about 70-75x of all Department of Defense benefictary care is provided in milltary facilities and about 25-30\% in the Civilian Health and Medical Program of the Uniformed Services funded civilian sector. 10 Even with the implementation of Civilian Health and Medical Program of the Uniformed Services reform initiatives the Department of Defense does not anticipate a substantial change in this ratio. Regional contracts will be undertaken in strict accordance with federal procurement regulations. Anticipated im plem entation of regional contracts is 0ctober 1987.

The effect of the Civilian Health and Medical Program of the Uniformed Service proposal on the Joint Health Benefits Delivery Program is not known, although several outcomes can be anticipated. Since more beneficiaries would be seen by civilian practitioners and hospitals that are members of the preferred provider network and the contractor would may be required to augment the medical staff in military health treatment facilities, the benefits of operating a Joint Health Benefits Delivery Program may be considered negiigible. Some benefit of implementing a Joint Health Benefits Delivery Program could be the by-product for com $m$ ands that are attuned to the medical needs of their beneficiarles and the shortfalls of the contractor through aggressive marketing of Joint Health Benefits Delivery Program services. Although prim ary care would be extensively provided via the contractor, the contractor would refer beneficiaries both military and civilian facilities for inpatient care.11 The beneficiary would retain the right to $m$ ake the decision concerning the facility to be utilized. Marketing the advantages of inpatient care in a military facility, particularly regarding free ancillary services and a nominal charge for meals, would be essential for any mi1ttary hospital competing with the Civilian Health and Medical Program of the Untformed Services regional contractor. 
1U.S., Department of Defense, Office of the Asststant Secretary of Defense for Health Affalrs, Fact Sheet: CHAMPUS Reform Inttiative, Septem ber 1985, D.3.

2Ibid., P.I.

3Joan B. Trauner, "The Second Generation of Selective Contracting: Another Look at PP OS," Journal of A mbulatory Care Management (May 1986): 13-17.

4U.S., Department of Defense, Dffice of the Assistant Secretary of Defense for Health Affalis, Fact Sheet: CHAMPUS Reform Initiative, Septem ber 1985, p.l.

5Ibid, pp. 2-3.

6Ibid, p.2.

7Ibid., p.3.

8 Ibid., p.2.

9Ibid., pp. 2-3.

10Ibid., p.2.

11U.S., Department of the Army Headquarters, United States Army Health Services Com m and, Implementation of Joint Health Benefits Delivery Program, June 1984, pp. 4-5. 


\section{CONCLUSION}

Comparison of inpatient civilian faciltty and Kenner Army Community Hospital estimates Indicated that utilization of the Joint Health Benefits Delivery Program as a mechanism for government cost savings would be a viable and cost effective option both for obstetrical and psychiatric services. Ftrst year obstetrical and psychiatric sum mary data reveal a difference in obstetrical and psychlatric service costs of $\$ 420,718.60$ as reflected below, demonstrating the feasibilfty of establishing outpatient psychlatric services under the Joint Health Benefits Delivery Program versus obstetrical services.

\section{Obstetrics $W$ ard and Psychiatric $W$ ard Total Cost (First Year)}

Psychiatric Ward

Staff

Equipment

Renovation

Supplies

Nutrition C are (Food, Labor, Supplies) Grand Total
$\$ 452,960.40$

$86,850.00$

$6,704.00$

$19,917.00$

$\underline{29,552.00}$

$\$ 595,983.40$ 
57

Obstetrics W ard

Staff

Equipment

Supplies

Renovation

Nutrition Care (Food, Labor, Supplies)

Grand Total
$\$ 583,310.00$

$383,575.00$

$20,817.00$

$39,800.00$

$34,200.00$

$\$ 1,016,702.00$

NOTE: Costs associated with relocation of current ward occupants were estimated as follows:

Relocation of NETS

Modify Building 8151A *

Construct NETS/P OT \&S Storage area

Build Partition (relocate Exec Housekeeper)
$\$ 22,500$

11,000

10,000

1,500

* Cost based upon estim ate of 250 square feet $\times \$ 70 /$ square foot. 
VII. RECOMMENDATIONS

Although the results of the feasibility study indicate that the establishment of a Joint Health Benefits Program for psychiatric services would appear to be more cost effective than obstetrical services, doing neither is also a viable option. The administration of the program as it is currently organized is considered by the Civilian Health and Medical Program of the Uniformed Services, Civilian Health and Medical Program of the Uniformed Services fiscal intermediaries, Civilian Health and Medical Program of the Uniformed Services field representatives, health benefits advisors, and medical treatment faciltty Commanders as administratively burdensome, confusing and time consuming. As previously discussed, the fact that active duty personnel cannot be treated under the Joint Health Benefits Delivery Program is also considered a negative aspect of the program, particularly given the medical treatment facility commander's priority $m$ ission to care for active $i . . . j$ service members. As mentioned in the Discussion chapter of this paper, events of the past year indicate that significant changes in the Civilian Health and Medical Program of the Untformed Services program in general, and the Joint Health Beneffts Delivery Program in particular, are soon to be directed by the Office of the Secretary of Defense for Health Affatrs. Given the results of the feasibility study and nonmonetary considerations such as program participation eligibility, the following recom mendations are presented for consideration: 
- Ascertain the specifics of the Civilian Health and Medical Program of the Untformed Services reform initiative prior to further implementation of services under the Joint Health Benefits Delivery Program. Civilian Health and Medical Program of the Uniformed Services reforms may reduce or curtall any current benefits of the Joint Health Benefits Delivery Program. Civilian Health and Medical Program of the Unfformed Services reforms could also make the implementation of the program more beneficial through adm inistratve and eligibility reforms.

- In the event that the executive management of the Kenner Army Community Hospital deems it necessary to implement the program with or without Civilian Health and Medical Program of the Uniformed Services reform Initiative information it is recommended they estabilish a Joint Health Benefits Delivery Program for psychiatric services. The following recom mendations should factlitate the successful $m$ anagem ent of the program:

a. One department in the hospital should be designated as the primary contact for all Joint Health Benefits Program activities to insure that issues are addressed expeditiously and consistently, and to insure program continuity. Recommend that the Patient Administration Division serve as the overall program facilitator. The Division's Health Benefits Advisor should be designated to serve in this capactty. Joint Health Benefits Delivery Program provider and patient care issues should be coordinated by the Chief, Clinical Support Division.

b. Establish a committee to plan the conversion of the third floor area for inpatient psychiatry. The committee's responstbilities should include planning and coordinating facilfty modifications, staffing, equipment, relocation of current occupants, education and training. 
c. Staffing of the Heaith Benefits Advisor's office should be com mensurate with the level of responsibilities. The one individual currently assigned to accomplish all Civilian Health and Medical Program of the Uniformed Services related tasks is not enough, frequently resulting in documentation backlogs and patient counseling delays.

d. Expansion or revision of the quality assurance and redentialing programs is recommended to insure the appropriateness of allowing contracted Joint Health Benefits Delivery Program provider's privileges.

e. An extensive marketing program should be developed prior to the establishment of the service. The marketing program should include, at a minimum: (1) education of the staff, psychiatrists in the com munity, beneficiary population, and key base support activities such as the Directorate of Engineering and Housing and (2) disse mination of information relative to the program in the Civilian Health and Medical Program of the Uniformed Service office, via community forums, post and community newspapers, and the central appointments system. 


\section{SELECTED BIBLIOGRAPHY}

$\underline{\text { Books }}$

Ashby, Betty S., Elliott, Jane T., Michalek, Ann M., Petrick, L., Reiss, L., Roth, A., Tuck, T., ad Williams, Sharon. Community Assessment of the City of Petersburg. Richmond, Virginia: Medical College of Virginia, 1984 .

Dixon, W. J. and Massey, F. J., Jr. Introduction to Statistical Analaysis (3rd ed.) New York: McGraw-H111, 1969.

Isaac, Stephen and Michael, William B. Handbook in Research and Evaluation. San Diego, California: Edits Publishers, 1982.

Resta, Paul E., and Baker, Robert L. Formulating the Research Problem. Inglewood, California: Southwest Reglonal Laboratory for Educational Research and Development, 1967.

\section{State and Local Government Documents}

V1rginia. Central Virginta Health Sygtems Agency, Inc. Physictan Ligtings by Zip Code. Richmond, Virginia, 1984.

Virginia. Virginia Health Services Cost Review Commission. Interpretation and Findings: Comparison of Hospital Charges as of February 1,1985 and Comparigon of Hospital Charges by Dlagnoses for the Month of Februar 1985. 1985 .

\section{Journals and Magazines}

Ermann, Dan. "Health Maintenance Organizations: The Future of the For-profit Plan." Journal of Ambulatory Care Management, 1986.

Iglehart, John $x$. "Medicare Turng to HMOs." The New England Journal of Medicine. Volume 312 , Number 2, January 1985.

Mott, Peter D. "Hospital Ut1lization by Health Maintenance Organizations." Medical Care, Volume 24, Number 5, May 1986.

Trauner, Joan B. "The Second Generation of Selective Contracting: Another Look at PPOs." Journal of Ambulatory Care Management, May 1986. 


\section{Intied States Government Documente}

U.S. Departinent of Defense. Civilian Health and Medical Program of the Uniformed Services. User's Guide for the CHAMPUS Cost and Workload/Health Care Summary Reports. January, 1985.

U.S. Department of the Army, Office of the surgeon General. Medical Summary Report - Section IV, Nonavallability Statenents (MED 302, R-3), october 1984 - September 1385 .

U.S. Department of Defense Civilian Health and Medical Program of the Uniformed Services. CHAMPUS Policy Manual, Volume II. June, 1983.

U.S. Department of Defense CHAMPUS. CHAMPUS Pollcy Manual, Volume II, June 2984.

U.S. Department of Defense CHAMPUS. CHAMPUS Pol1cy Manual, Volume I, December, 1982.

U.S. Department of Defense. CHAMPUS Handbook. CHAMPUS No. 6010.46-H. Aurora Colorado 1985.

U.S. Department of Defense. CHAMPUS Handbook. CHAMPUS 60.10.46-H. Aurora, Colorado, January 1986.

U.S. Department of Defense Instruction. Joint Health Benefits Delivery Program. Number 6010.12, February, 1983.

U.S. Department of Defense. CHAMPUS Maternity Care. CHAMPUS FS-8, Aurora, Colorado. $19 \overline{85}$

U.S. Department of Defense, Office of the Assistant Secretary of Defense for Health-Affairs. Fact Sheet: CHAMPUS Reform Init lattve. September 1985.

U.S. Department of the Army Headquarters, United States Health Services Command. Implementation of Joint Health Benefits Delivery Program, June, 1984.

U.S. Department of the Army Headquarters, United States Health Services Command. Mission Assignment List (HSC Form 276-R). June 1984.

U.S. Department of the Army, United States Army Health Services Command Biostatistical Activity. Nonavallability Siatements Summary for Health Services Command. March 1985.

\section{Rerort}

Medical Department Activity, "Comptrcller's Population Supported Report." Fort Lee, Virginia. November 1985. 